\title{
Jobbszívfél-elégtelenség évekkel a szívtranszplantációt követöen: Egy ritka etiológiai tényező esete
}

\author{
Parázs Nóra', Lakatos Bálint Károly', Kovács Attila', Assabiny Alexandra', \\ Király Ákos', Tarjányi Zoltán', Szakál-Tóth Zsófia', Teszák Tímea', Tokodi Márton', \\ Ujvári Adrienn', Kugler Szilvia', Szücs Nikolette², Merkely Béla ${ }^{1 *}$, Sax Balázs ${ }^{1 *}$
}

\author{
'Semmelweis Egyetem, Városmajori Szív- és Érgyógyászati Klinika, Budapest \\ ${ }^{2}$ Semmelweis Egyetem, Belgyógyászati és Onkológiai Klinika, Budapest \\ Levelezési cím: \\ Dr. Parázs Nóra, 1122 Budapest, Városmajor utca 68. E-mail: nora.parazs@gmail.com
}

\begin{abstract}
Esetismertetésünkben négy évvel a szívtranszplantációt követően kialakult jobbszívfél-elégtelenség ritka etiológiai tényezőjét mutatjuk be. 66 éves férfi betegünknél egy évvel a szivátültetést követően egy rutinkivizsgálás alkalmával derült fény a májban elhelyezkedő jól differenciált neuroendokrin tumor metasztázisára. További vizsgálatok során a primer tumort azonosítani nem sikerült, specifikus terápia ekkor nem indult. Sorozat echokardiográfiás vizsgálatain mindvégig jó graftfunkció, normál üregméretek ábrázolódtak ép billentyűk mellett. Négy évvel a transzplantációt követően fokozódó nehézlégzés miatt vizsgáltuk betegünket. Az elvégzett echokardiográfiás vizsgálat tág, csökkent funkciójú jobb kamrát, a tricuspidalis billentyün koaptációs defektust, következményes súlyos fokú regurgitációt véleményezett. $\mathrm{A}$ látott kép hátterében a neuroendokrin tumor ismeretében karcinoid valvulopathiát véleményeztünk. $\mathrm{A}$ lehetséges tumorprogresszióra tekintettel számos vizsgálatot végeztünk a primer tumor azonosítása céljából, amelyet igazolni még Octreoscan-nel sem tudtunk. A betegnél hosszú hatású szomatosztatin-analóg, valamint a jobbszívfél-elégtelenségére tekintettel kombinált diuretikus gyógyszeres terápiát vezettünk be, amely mellett betegünk stabil, kielégítő funkcionális stádiumban van.
\end{abstract}

Kulcsszavak: karcinoid valvulopathia, jobbszívfél-elégtelenség, tricuspidalis regurgitáció, neuroendokrin daganat, szívtranszplantáció

Right heart failure many years after heart transplantation - a case of a rare etiology

We present a case of patient with a rare etiological factor for right heart failure 4 years after heart transplantation. Annual follow-up revealed a liver metastasis of a well-differentiated neuroendocrine tumor in our 66 year-old male patient one year after uneventful heart transplantation. This time, no specific therapy was initiated as the primary source of the metastasis could not be identified. The regular echocardiographic examinations showed excellent graft function with normal chamber diameters and intact valves. Four years after heart transplantation the patient presented with shortness of breath and echocardiography revealed severely dilated right ventricle with reduced function, a coaptation defect of the tricuspid valve with corresponding severe regurgitation. Due to the established presence of a neuroendocrine metastasis, we have diagnosed carcinoid valvulopathy and attempted again to localize the primary source with Octreoscan, unsuccessfully. We initiated long-lasting somatostatin analog, along with combined diuretic therapy. Our patient is still doing well with a compensated functional status.

Keywords: carcinoid valvulopathy, right heart failure, tricuspid regurgitation, neuroendocrine tumor, heart transplantation

*A szerzők azonos mértékben járultak hozzá a közleményhez.

A kézirat 2021. 02. 05-én érkezett a szerkesztőségbe, 2021. 02. 23-án került elfogadásra. 


\section{Bevezetés}

A szívtranszplantációt követő első posztoperatív évben a primer graftelégtelenség, az allograft-rejekció és az infekciók határozzák meg a mortalitási mutatókat, a későbbiekben azonban megnő a száma a malignus betegségek kialakulásának. A szívtranszplantációt követő korai posztoperatív időszakban gyakran látunk jobbszívfél-adaptációs zavart, esetünkben azonban egy késői jobbszívfél-elégtelenség és annak ritka etiológiai tényezőjét, egy neuroendokrin tumor által kiváltott karcinoid szívbetegséget szeretnénk bemutatni.

\section{Esetismertetés}

66 éves férfi betegünk 2012 áprilisában esett át ortotopikus szívátültetésen végstádiumú iszkémiás szívbetegség miatt a Városmajori Szív- és Érgyógyászati Klinikán. Eseménytelen posztoperatív periódust követően 2013 áprilisában betegünknél rutin éves kivizsgálás alkalmával készült hasi ultrahang írt le a máj állományában néhány kisebb, kifejezetten echoszegény kerekded képletet. A képletek pontosabb karakterizálása céljából célzott máj-MRI-vizsgálatot végeztünk, amely a máj mindkét lebenyében multiplex hipervaszkularizációt mutató noduláris elváltozást véleményezett. A morfológiai kép nem volt specifikus, így malignitás kizárása céljából ultrahangvezérelt biopszia elvégzése mellett döntöttünk. A bioptátum szövettani vizsgálata jól differenciált neuroendokrin tumort igazolt, immunhisztokémiai vizsgálattal a tumorsejtekben diffúz erős kromogranin-A-pozitivitás volt látható, Ki-67 2-3\% volt. A szövettani lelet a májtumort metasztázisnak valószínúsítette, így a primer tumor kutatása céljából szomatosztatinreceptor-szcintigráfiát végeztünk, azonban primer daganatot nem sikerült igazolnunk. Immunszuppresszív gyógyszeres terápiáját az időközben kialakult, intervenciót igénylő koszorúér-betegségre (kardiális allograft-vasculopathia) és a daganatra tekintettel optimalizáltuk, tacrolimust az irodalomban is javasolt everolimusra cseréltük (1). Echokardiográfiás vizsgálatai során mindvégig normál tág kamrák, jó bal és jobb kamra szisztolés funkció ábrázolódott, enyhe fokú mitrális és tricuspidalis regurgitáció mellett.

2016-ban, 4 évvel a szívtranszplantációt követően betegünket fokozódó nehézlégzés miatt vizsgáltuk klinikánkon. Panaszai hátterében jelentős mennyiségủ pleurális fluidumot diagnosztizáltunk. Echokardiográfiás vizsgálata (1. táblázat) során tág, csökkent funkciójú jobb kamra ábrázolódott (1. és 2. ábra) a szeptumon diasztolés D-jellel, továbbá súlyos fokú tricuspidalis regurgitáció ábrázolódott döntően az anterior vitorla retrakciója talaján (3. ábra), koaptációs defektussal. A látott echokardiográfiás képre tekintettel panaszai hátterében jobbszívfél-elégtelenség oki szerepét véleményeztük (akut rejekciót és a koszorúér-betegség romlá-
1. TÁBLÁZAT. A karcinoid valvulopathia kialakulása előtti, illetve utáni jobb és bal kamrai morfológiai és funkcionális paraméterek

\begin{tabular}{c|c|} 
2015. évi & 2016. évi \\
echokar- & echokar- \\
diográfiás & diográfiás \\
vizsgálat & vizsgálat
\end{tabular}

\begin{tabular}{|c|c|c|}
\hline $\begin{array}{l}\text { Jobb kamra bazális } \\
\text { átmérő }(\mathrm{mm})\end{array}$ & 35 & 48 \\
\hline TAPSE (mm) & 18 & 13 \\
\hline $\begin{array}{l}\text { Frakcionális jobb kamrai } \\
\text { area változás }(\%)\end{array}$ & 47 & 33 \\
\hline $\begin{array}{l}\text { Jobb kamra szabad fali } \\
\text { longitudinális strain (\%) }\end{array}$ & -23 & -16 \\
\hline $\begin{array}{l}\text { 3D jobb kamrai végdiasz- } \\
\text { tolés volumenindex }\left(\mathrm{ml} / \mathrm{m}^{2}\right)\end{array}$ & 44 & 112 \\
\hline $\begin{array}{l}\text { 3D jobb kamrai végsziszto- } \\
\text { lés volumenindex }\left(\mathrm{ml} / \mathrm{m}^{2}\right)\end{array}$ & 22 & 69 \\
\hline $\begin{array}{l}\text { 3D jobb kamrai } \\
\text { ejekciós frakció (\%) }\end{array}$ & 50 & 39 \\
\hline $\begin{array}{l}\text { 3D bal kamrai végdiaszto- } \\
\text { lés volumenindex }\left(\mathrm{ml} / \mathrm{m}^{2}\right)\end{array}$ & 54 & 74 \\
\hline $\begin{array}{l}\text { 3D bal kamrai végszisztol- } \\
\text { és volumenindex }\left(\mathrm{ml} / \mathrm{m}^{2}\right)\end{array}$ & 21 & 37 \\
\hline $\begin{array}{l}\text { 3D bal kamrai ejekciós } \\
\text { frakció }(\%)\end{array}$ & 61 & 50 \\
\hline $\begin{array}{l}\text { Bal kamrai globális } \\
\text { longitudinális strain (\%) }\end{array}$ & $-18,5$ & $-18,5$ \\
\hline
\end{tabular}

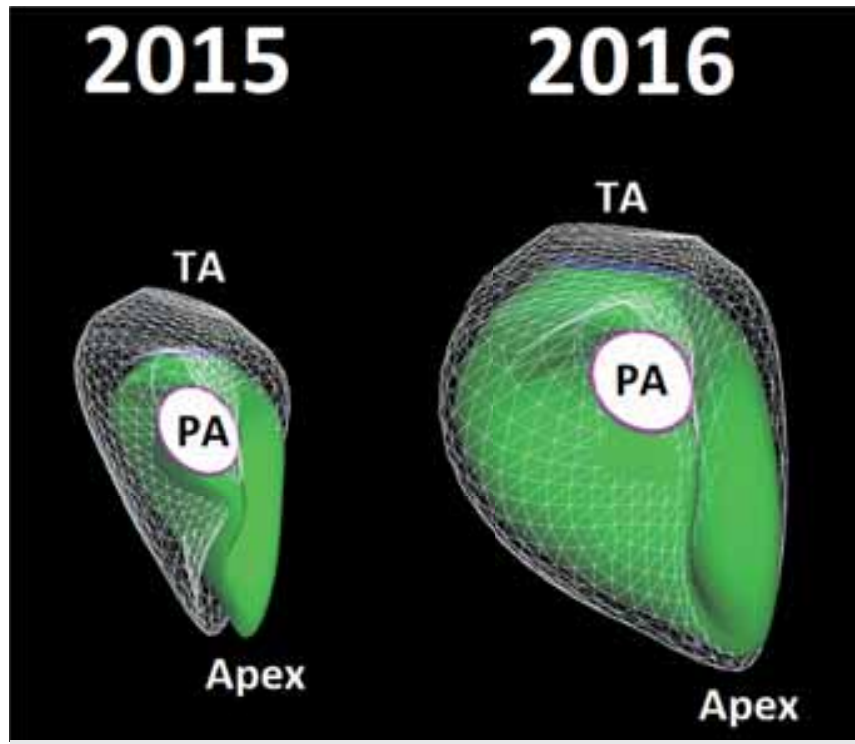

1. ÁBRA. A jobb kamra 3D-echokardiográfiás rekonstrukciója a 2015-ös éves kontrollvizsgálat során, illetve a panaszok jelentkezésekor. A fehér háló a végdiasztolés, a zöld felszín a végszisztolés volument reprezentálja. Mind morfológiailag, mind funkcionálisan jelentős a különbség: a korábbi normál dimenziójú, megtartott ejekciós frakciójú jobb kamra a volumenterhelés következtében masszívan dilatált és diszfunkcióssá vált (1. TÁBLÁZAT). TA: tricuspidalis anulus, PA: pulmonalis anulus 


\section{5}

\section{6}
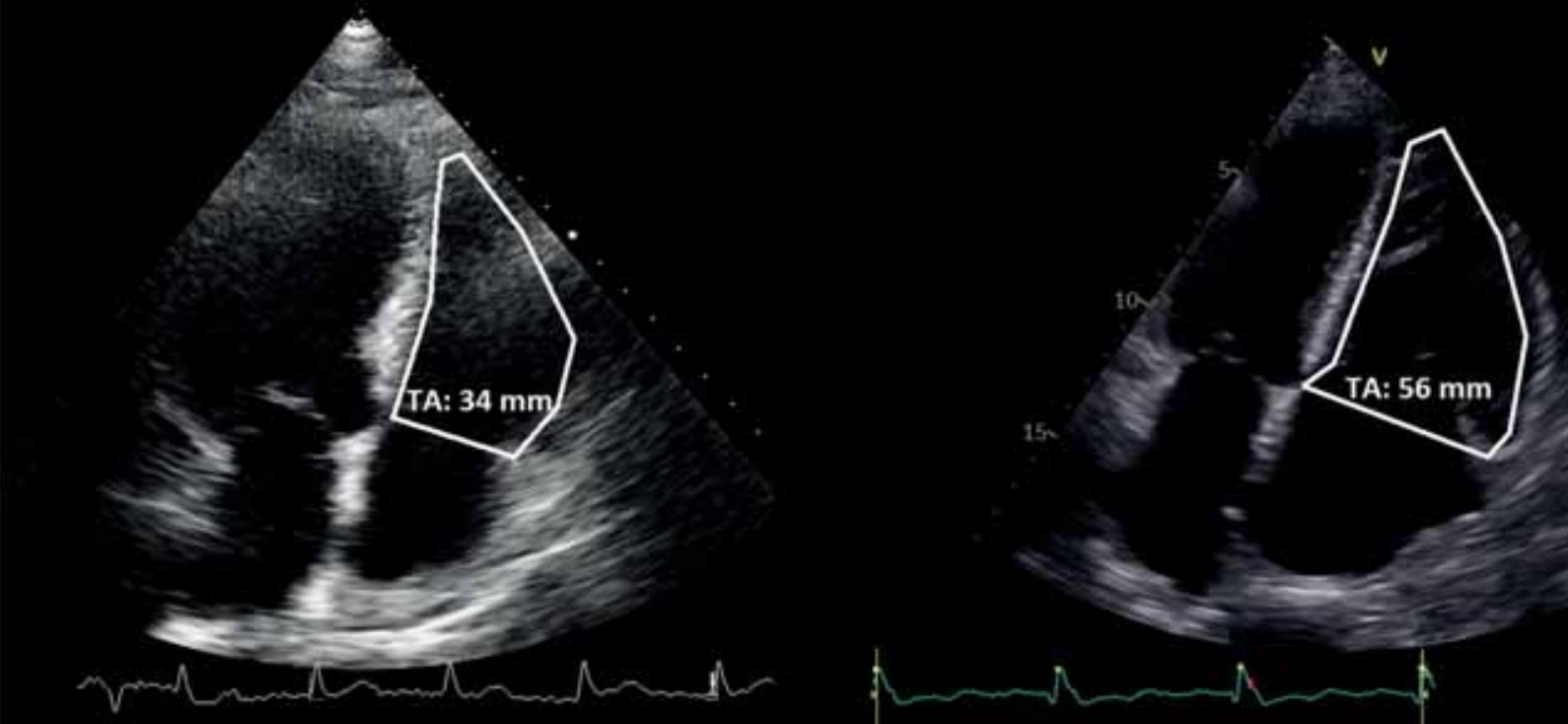

2. ÁBRA. Jobb kamrára fókuszált apikális négyüregű metszetek a 2015-ös éves kontrollvizsgálat során, illetve a panaszok jelentkezésekor (végdiasztolés frame-ek, a fehér kerület a jobb kamra endokardiális felszínét reprezentálja). A morfológiai különbség (különös tekintettel a tricuspidalis anulus (TA) lineáris átmérőjére) szembeötlö

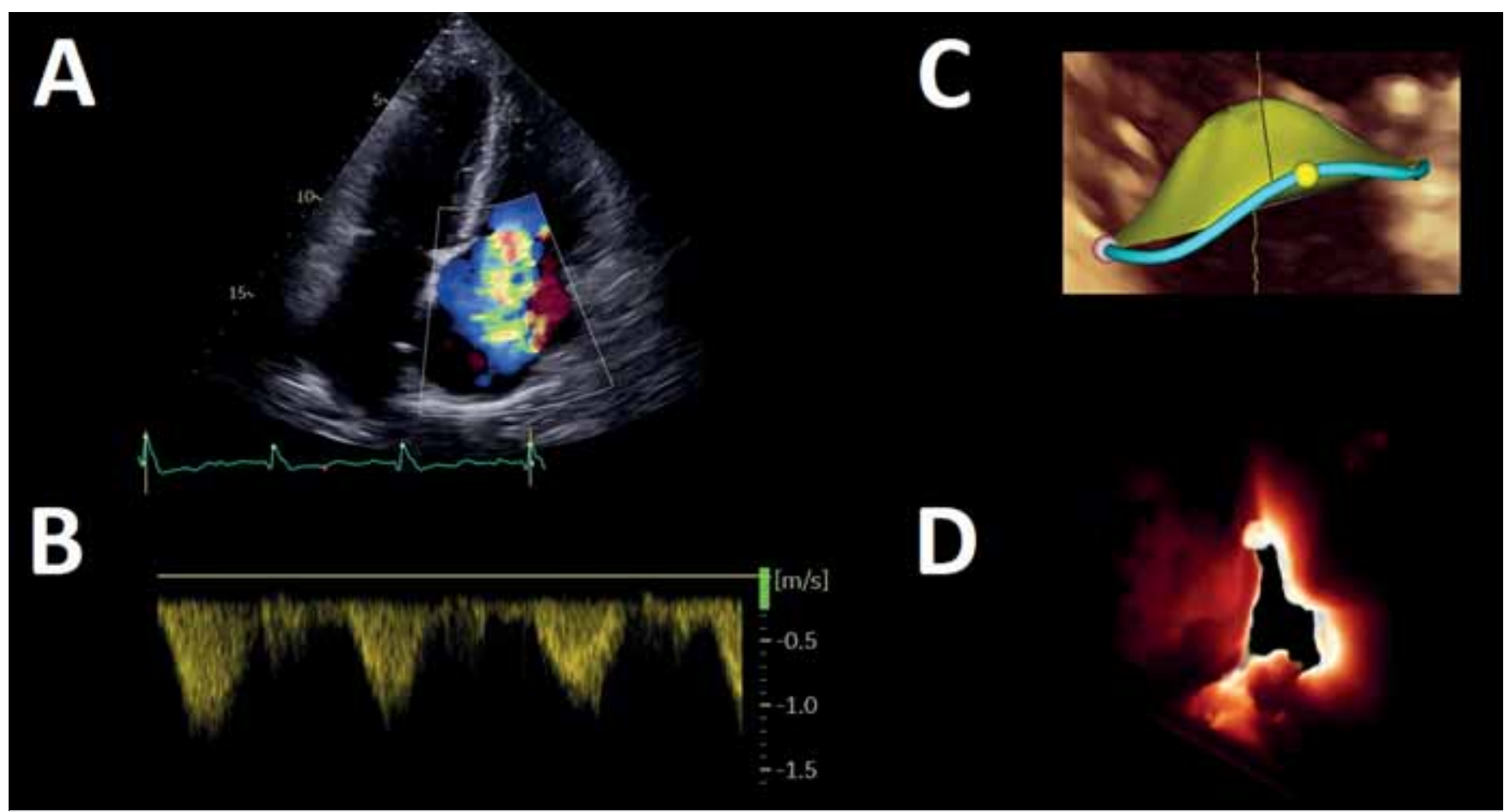

3. ÁBRA. „A" PANEL: torrenciális tricuspidalis regurgitáció jelentős koaptációs defektus talaján. „B” PANEL: CW spektrális Doppler-interrogáció, amelyen jól látszik a súlyos fokú tricuspidalis regurgitáció jellegzetes képe (alacsony csúcssebesség, tőr alak). "C" PANEL: a tricuspidalis anulus 3D rekonstrukciója. Az anulus area tágult $\left(17,9 \mathrm{~cm}^{2}\right)$, a vitorla tenting volumen szintén jelentős (8,5 ml). „D” PANEL: 3D „volume rendering” rekonstrukció a tricuspidalis vitorlákról a kamrai oldal felöl nézve (midszisztolés frame). Jól látható a koaptációs defektus összetett és jelentős felszíne

sát kizártuk), amelyet a hasi ultrahangon leírt ascites is alátámasztott. A súlyos fokú tricuspidalis regurgitáció hátterében, az anamnézisben szereplő neuroendokrin tumorra is tekintettel karcinoid valvulopathia etiológiá- ját véleményeztük, amelyet a karcinoid szindrómában gyakori hasmenéses panaszok is megerősítettek.

A lehetséges tumorprogresszióra tekintettel ismét a primer tumor kutatásába kezdtünk. Bronchoszkópiát, 
pleurocentézist, gasztroszkópiát, kolonoszkópiát valamint Octreoscan-vizsgálatot végeztünk, amelyek primer neuroendokrin tumort nem igazoltak. A karcinoid szívbetegségre tekintettel a betegnél szomatosztatin-analóg, hosszú hatású octreotidkezelést kezdtünk. Betegünk a beállított kombinált diuretikus terápia (kacsdiuretikum, mineralokortikoid-receptor-antagonista) és octreotidkezelés mellett kielégítő funkcionális stádiumban (NYHA II.), teljes életet tud élni. A valvulopathia további progresszióját nem észleltük.

\section{Megbeszélés}

A karcinoid tumor az emésztőrendszer és a tüdő jól differenciált neuroendokrin daganata, amely számos vazoaktív anyagot termel, föként szerotonint (2). A karcinoid tumorok az esetek akár $60 \%$-ában okozhatnak szívérintettséget $(3,4)$. Karcinoid szívbetegség akkor alakul ki, amikor nagy mennyiségű vazoaktív anyag, például szerotonin, tachykinin és prosztaglandin, amelyeket a máj nem tud inaktiválni (5), a hepatikus vénákon keresztül elérik a szisztémás keringést (6). Endocardiumkárosodást követően, fibroblasztból, simaizomból és extracelluláris mátrixból (7) álló plakkdepozitumok keletkeznek a jobb szívfél billentyüinek endokardiális felszínén, a papilláris izmokon és ínhúrokon (8). Karcinoid valvulopathiában leggyakrabban tricuspidalis regurgitációt látunk; a billentyű vitorlái megvastagodnak, az ínhúrok megrövidülnek, rigiddé válnak, valamint súlyos esetben koaptációs hiány jön létre (4). A látott strukturális és valvuláris eltérések jobbszívfél-elégtelenséghez vezetnek (9). Kezelés nélkül a karcinoid szívbetegség rossz prognózisú, a 3 éves túlélés mindössze $31 \%$ (vs. $68 \%$ azon betegeknél, akiknél karcinoid szívbetegség nem alakul ki) (4). A karcinoid valvulopathia definitív megoldását gyógyszeres terápiára refrakter esetekben a tricuspidalis billentyű cseréje jelenti (10).

\section{Következtetés}

Bár a szívtranszplantációt követő késői halálozásban a daganatos betegségek élen járnak, esetünkben is látható, hogy egy kezelt neuroendokrin daganattal, valamint az általa okozott karcinoid szívbetegséggel, rendszeres kardiológiai gondozás és jól beállított gyógyszeres terápia mellett minőségi, hosszú életet lehet élni.

\section{Nyilatkozat}

A szerzők kijelentik, hogy az esetismertetés közlemény megírásával kapcsolatban nem áll fenn velük szemben pénzügyi vagy egyéb lényeges összeütközés, összeférhetetlenségi ok, amely befolyásolhatja a közleményben bemutatott eredményeket, az abból levont következtetéseket vagy azok értelmezését.

Irodalom

1. Yao JC, Fazio N, Singh S, et al. Everolimus for the treatment of advanced, non-functional neuroendocrine tumours of the lung or gastrointestinal tract (RADIANT-4): a randomised, placebo-controlled, phase 3 study. Lancet 2016; 387: 968-77.

https://doi.org/10.1016/S0140-6736(15)00817-X

2. Onaitis MW, Kirshbom PM, Hayward TZ, et al. Gastrointestinal carcinoids: characterization by site of origin and hormone production. Ann Surg 2000; 232: 549-56

https://doi.org/10.1097/00000658-200010000-00010

3. Lundin L, Norheim I, Landelius J, et al. Carcinoid heart disease: relationship of circulating vasoactive substances to ultrasound-detectable cardiac abnormalities. Circulation 1988; 77: 264-9.

https://doi.org/10.1161/01.cir.77.2.264

4. Pellikka PA, Tajik AJ, Khandheria BK, et al. Carcinoid heart disease. Clinical and echocardiographic spectrum in 74 patients. Circulation 1993; 87: 1188-96. https://doi.org/10.1161/01.cir.87.4.1188

5. Fox DJ, Khattar RS. Carcinoid heart disease: presentation, diagnosis, and management. Heart 2004; 90: 1224-8.

https://doi.org/10.1136/hrt.2004.040329

6. Davar J, Connolly HM, Caplin ME, et al. Diagnosing and Managing Carcinoid Heart Disease in Patients With Neuroendocrine Tumors: An Expert Statement. J Am Coll Cardiol 2017; 69: 1288-304. https://doi.org/10.1016/j.jacc.2016.12.030

7. Grozinsky-Glasberg S, Grossman AB, Gross DJ. Carcinoid Heart Disease: From Pathophysiology to Treatment - "Something in the Way It Moves”. Neuroendocrinology 2015; 101: 263-73.

https://doi.org/10.1159/000381930

8. Ram P, Penalver JL, Lo KBU, et al. Carcinoid Heart Disease: Review of Current Knowledge. Tex Heart Inst J 2019; 46: 21-27.

https://doi.org/10.14503/THIJ-17-6562

9. Møller JE, Pellikka PA, Bernheim AM, et al. Prognosis of carcinoid heart disease: analysis of 200 cases over two decades. Circulation 2005; 112: 3320-7.

https://doi.org/10.1161/CIRCULATIONAHA.105.553750

10. Connolly HM, Schaff HV, Abel MD, et al. Early and Late Outcomes of Surgical Treatment in Carcinoid Heart Disease. J Am Coll Cardiol 2015; 66: 2189-96. https://doi.org/10.1016/j.jacc.2015.09.014 